\title{
$6^{\circ}$ CONGRESSO NACIONAL DE BIBLIOTECÁRIOS, ARQUIVISTAS E DOCUMENTALISTAS
}

\author{
AVEIRO, 6-8 DE MAIO DE 1998
}

\section{CONCLUSÕES E RECOMENDAÇÕES}

1. No contexto actual das rápidas e profundas mudanças que se operam nos domínios da produção, comunicação, distribuição e uso da informação, com irreversíveis efeitos sociais, políticos e económicos, de contornos e alcance ainda não determináveis, as bibliotecas, arquivos e, em geral, todo o tipo de serviços de documentação e informação, devem assumir-se, e ser considerados, como elementos chave para a construção da chamada Sociedade da Informação.

2. A construção da Sociedade da Informação requer mais do que uma mera assumpção política, expressa por desígnios globais formulados ao nível superior das instâncias oficiais. Requer a definição de linhas de acção, o estabelecimento de programas de actuação e a sua concretização no terreno das funções e actividades institucionais, de uma forma orientada por objectivos fundamentais comuns, por prioridades gerais claramente identificadas e por estratégias de integração tecnológica e organizacional que permitam corresponder às expectativas da sociedade em termos da capacidade e da qualidade de acesso universal à informação.

3. No âmbito das bibliotecas e arquivos portugueses a situação presente é ainda, essencialmente, de expectativa e início de transformação face ao novo contexto. Uma transformação que as instituições devem operar, não apenas pela simples adesão à tecnologia, mas de modo estrutural e integrado, sem deixar de recolher, dos modelos organizacionais e técnicos desenvolvidos ao longo de décadas, a experiência e os princípios que permaneçam válidos.

4. Essa transformação exige hoje atitutes e intervenções essencialmente programáticas, que o $6^{\circ}$ Congresso Nacional de Bibliotecários, Arquivistas e Documentalistas reconhece, recomendando aos profissionais, aos órgãos decisores das instituições e às instâncias políticas:

a) Maior intervenção das instituições e empenhamento dos profissionais no sentido de reforçar a participação activa das bibliotecas e arquivos na rede global, enquanto organismos fornecedores e intermediários de serviços electrónicos de informação, expandindo e renovando o seu papel fundamental na concretização dos direitos dos cidadãos em matéria de acesso à informação. 
b) Evolução das funções de gestão de informação das bibliotecas e arquivos no sentido da integração dos recursos documentais tradicionais com os recursos digitais, numa perspectiva de serviços de rede que sirva a óptica do utilizador, independentemente dos formatos e modos de acesso dos documentos;

c) Promover a intervenção dos serviços e profissionais de arquivo na gestão documental, nomeadamente na produção, utilização e avaliação de documentos;

d) Adopção das normas relevantes para aplicação das novas tecnologias, nomeadamente no que respeita às questões relacionadas com o funcionamento em rede, de modo a garantir a intercomunicabilidade e transparência de serviços e produtos;

e) Definição de estratégias e concretização de investimentos para a criação de bibliotecas e arquivos digitais, visando o desenvolvimento de novas formas de acesso e difusão em rede aos conteúdos fundamentais do património histórico e cultural à guarda das bibliotecas e arquivos;

f) Criação de novas estruturas, legais e técnicas, visando o controlo bibliográfico, selecção e arquivo de informação electrónica distribuída em rede, função altamente relevante no contexto actual da Internet, que deverá ser assumida pela Biblioteca Nacional, responsável pela conservação da memoria documental Portuguesa;

g) Introdução e desenvolvimento de novas competências profissionais, factor crucial para o sucesso da renovação dos serviços de informação, nomeadamente nos aspectos que se relacionam com as tecnologias de informação, o que implica uma urgente reestruturação da formação de base dos novos profissionais, e passa também por uma estratégia decisiva e consistente de formação contínua dos profissionais no activo;

h) Adopção de medidas de política visando um decisivo investimento público no sector das bibliotecas e arquivos, independentemente das suas diversas tutelas, que permita às instituições o acesso aos meios financeiros, técnicos e humanos, absolutamente indispensáveis à salvaguarda do seu património, ao desenvolvimento consistente dos seus recursos locais de informação e à prossecução inadiável dos seus objectivos de modernização.

i) Aumentar o investimento, das tutelas oficiais e das organizações, na criação ou reforço dos mecanismos de cooperação inter-institucional, base essencial da construção de serviços de informação em rede, que tenderão a ser integrados e transparentes na óptica do cidadão e racionalizadores de recursos na óptica das instituições, sem prejuízo da sua identidade, perfil e vocação específicos; 
Alargamento dessa cooperação ao nível internacional, de forma a contribuir para a realização de uma Sociedade da Informação sem fronteiras, dinamizando o efectivo intercâmbio de experiências técnicas e a partilha de recursos de informação, em iniciativas transnacionais que ajudem a promover a cultura portuguesa no Mundo. 
